DOI 10.18551/rjoas.2021-09.14

\title{
MARKET INTEGRATION OF TILAPIA FISH (OREOCHROMIS NILOTICUS) FROM FRESHWATER CULTIVATION IN SOUTH KALIMANTAN PROVINCE OF INDONESIA
}

\author{
Lilimantik Emmy*, Mailita \\ Faculty of Fisheries and Marine, University of Lambung Mangkurat, \\ South Kalimantan, Indonesia \\ *E-mail: emmy.lilimantik@ulm.ac.id
}

\begin{abstract}
This study aims to determine the market integration of tilapia fish (Oreochromis niloticus) from freshwater cultivation in South Kalimantan Province. The data used are primary data and secondary data, while the data collection uses the methods of observation, interviews and documentation. The sampling method of cultivators uses simple random sampling method, while the sample of marketing institutions uses the snowball sampling method. The data analysis used is (a) marketing channel analysis and (b) market integration analysis. The results of the analysis show that (a) marketing channels of tilapia fish consist of 4 patterns, which are (1) one of fish farmer (3\%) sold the fish out to the consumer, (2) twenty five of fish farmers $(78 \%)$ sold the fish out to the middleman and then sold again to retailers and finally sold to the final consumers, (3) four of fish farmers (13\%) sold the fish out to the retailers and distributed to consumers and (4) two of fish farmers sold the fish out to the institutional market for distributed to consumers and (b) the value of the regression coefficient $(\beta)$ is 0.55 . The value of $<1$ explains that the market is not perfectly integrated, while the market structure is an oligopsony market.
\end{abstract}

\section{KEY WORDS}

Fish cultivation, tilapia fish, fish farmer, middlemen, retailers, marketing channel.

Fish cultivation is a process made to increase the production of fishery products without harming the sustainability of aquatic resources, improve fish stocks in nature through efforts to enhancement fish stocks by restocking in waters that experience overfishing and provide fish continuously regardless of the season (Wonginyoo $\mathrm{K}$, Piewthongngam $\mathrm{K}$, Chatavithee $P$ and Vorasay J., 2018). Freshwater fish farming business opportunities are now increasingly being looked at as a promising business opportunity along with the increasing market demand for fishery products (Saugat K, Sushil K and Saurav K., 2020). One type of freshwater fish that has been favored by cultivators is tilapia, known for its delicious and savory meat taste, fast growth with 4 to 6 months for enlargement to meet standard sizes for consumption (Dampin N, Maleewong M, 2012). Tilapia is also quite strong against disease disorders so the maintenance is easy and the cost is cheap, but the results are relatively profitable (Kapute F, Valeta J, Jeremy $L$ and Jeremiah K., 2016). Tilapia is one of the leading commodities of freshwater aquaculture in South Kalimantan with the amount of production as shown in Table 1.

Table 1 - Total production of tilapia from freshwater aquaculture in 2011-2020

\begin{tabular}{lll}
\hline No. & Year & Tilapia fish (ton/year) \\
\hline 1. & 2011 & 32.443 .0 \\
2. & 2012 & $32.673,5$ \\
3. & 2013 & $29,883,3$ \\
4. & 2014 & $30.764,5$ \\
5. & 2015 & $36.625,8$ \\
6. & 2016 & $50.358,9$ \\
7. & 2017 & $49.289,8$ \\
8. & 2018 & $49.440,8$ \\
9. & 2019 & $49.488,2$ \\
10. & 2020 & $49.560,3$ \\
\hline
\end{tabular}

Source: Dinas Perikanan and Kelautan, 2021. 
Throughout 2011-2020, tilapia production increased due to the relatively easy way of cultivation with not too large capital, has fast growth with a shorter harvest period and has a promising selling value at a high enough price (Ariadi H, Meilissa M.C, Elyah $F$ and Mardiana, 2021). The high price of tilapia is the main attraction for producers and traders to sell fish to main markets in several areas in South Kalimantan, thus enabling the movement of tilapia from production areas to consumption areas relatively quickly (Lilimantik, 2013). Tilapia prices in South Kalimantan in 2020 shown in Table 2.

Table 2 - Price of tilapia fish in South Kalimantan Province in 2020

\begin{tabular}{lll}
\hline No. & District/City & Price (IDR/kg) \\
\hline 1. & Tanah Laut & 37.000 \\
2. & Kotabaru & 40.000 \\
3. & Banjar & 30.000 \\
4. & Barito Kuala & 36.000 \\
5. & Tapin & 38.000 \\
6. & Hulu Sungai Selatan & 40.000 \\
7. & Hulu Sungai Tengah & 39.000 \\
8. & Hulu Sungai Utara & 39.000 \\
9. & Tabalong & 35.000 \\
10. & Tanah Bumbu & 38.000 \\
11. & Balangan & 35.000 \\
12. & Banjarmasin & 34.000 \\
13. & Banjarbaru & 32.000 \\
\hline
\end{tabular}

Source: Dinas Perikanan and Kelautan, 2021.

The high price at the producer level will have a positive impact, this is because the profits obtained will be greater and will stimulate producers to increase the amount of production, and vice versa (Ngo T., et al, 2019). Information about market prices between regions must be disseminated to all relevant parties such as producers, marketing institutions and consumers so that they are able to support the formation of strong price ties (Kemisola, O.A and Anifat, O.B., 2010). Understanding the level of market integration will facilitate monitoring of price changes, and can also be used as a basis for improving policies that are more relevant to the development of fisheries markets in an area (Eltholth $\mathrm{M}$, Fornace $\mathrm{K}$, Grace D, Rushton J and Hasle B., 2015). Price closeness can be determined based on the formation of the price of a commodity at the level of certain marketing institutions which is apparently influenced by prices at the level of other marketing institutions (Mafimisebi T.E., 2008). Price closeness will occur if the price conditions at the next level are the same as the price at the current level plus marketing costs (Heytens, 1986). Strong market integration indicates that the marketing process of a commodity becomes efficient, because the price will be transformed appropriately to other markets both vertically and horizontally (Ravallion, 1986).

Anindita and Baladina (2017) explain that in an efficient market structure, the slightest price changes that occur in a market will cause prices to fluctuate. Prices at the retail level will be the basis for determining prices to be paid to intermediary traders and ultimately to producers and vice versa (Kartikasari D, 2010). Furthermore, the price received by farmers will determine how large the volume of production produced by producers is to be sold to middlemen or retailers (Lilimantik E, Ahmadi., 2020). If the price received is satisfactory, the production offered to the market will also increase, and vice versa (Hanafiah and Saefuddin, 1996).

\section{MATERIALS AND METHODS OF RESEARCH}

This research conducted in South Kalimantan Province, where the research was determined intentionally (purposive sampling) with the consideration that Kalimantan Province has several areas that cultivate tilapia, with the largest area being in Banjar Regency and then moved into local fish markets located in Martapura, Banjarbaru, Banjarmasin, Barabai and Pelaihari of South Kalimantan Province. 
A total of 51 respondents who directly involved in marketing channels were selected comprising 32 fish farmers, 7 wholesalers and 12 retailers. The age of respondents varied between 33-52 years old with the duration of business experience range of 2-6 years.

The data was collected use observation, interview and documentation method. Observation method is a method that collects data directly from the field for the success and accuracy of research results (Ciesielska M, Bostrom K.W and Ohlander M., 2008). The interview method is an event or a process of interaction between the interviewer and interviewee through direct communication (Gubrium J.F and Holstein J.A., 2013). In the interview techniques, there are two known approach methods, namely structured interviews in which the interviewer prepares to conduct interviews with respondents, while the other one is the unstructured interviews, where the interviewer does not prepare a list of questions and the question is carried out spontaneously (Corbin J, Morse JM., 2003). While the documentation method is used to obtain data through facts stored in the form of letters, diaries, photo archives, meeting results, souvenirs, activity journals and so on (Bowen, G.A., 2009).

The data used are primary and secondary data. Generally, these two data are combined to complement each other and assist researchers in observing any existing phenomena. (Rabinovich, E. \& Cheon, S., 2011). Primary data is data obtained directly from the first source by using measurement tools or data collection tools directly on the subject as the source of information sought (Kabir SMS, 2016), while secondary data is data that is not obtained directly by researchers, for example research must go through others or searching through documents (Johnston, MP, 2014). Secondary data is obtained through books, government publications, internal organization records, reports, journals, to various sites related to the information being sought (Martins, F., Cunha, J., \& Serra, F., 2018).

The sampling method for tilapia cultivations is the simple random sampling method system, a sampling technique which is a method of drawing random members of the population regardless of the strata in the population (Singh S, 2003) so that each member of the population has an equal chance of being selected. Equally to be elected (Castle JE, 2003). This method is carried out if the members of the population are considered homogeneous (West, P., 2016).

Then the sampling of marketing agencies (i.e. middlemen, retailers) uses the snowball sampling method, which is a method for identifying, selecting and taking samples in a continuous network or chain of relationships (Blanken P, 1992), or sampling techniques that are initially small in number, then this sample selects its peers to be sampled and so on until the number of samples collected increase (Atkinson, R. and Flint, J., 2001).

The pattern of marketing channels for tilapia cultivation in South Kalimantan Province was analyzed by descriptive method, by analyzing each of the marketing institutions involved and the marketing channels they went through from the producer level (fish cultivators) to the consumer level (Parmar G, Leua A and Vanza J., 2018).

Market integration analysis can be searched using standard static models such as simple regression which aims to test the law of one price with the assumption that if the prices of other factors remain constant, then prices at the producer level and prices at the consumer level are linear (Unget D, Mahreda E, Lilimantik E., 2020). The simple linear regression equation model can be seen in equation 1 .

$$
\mathrm{Pf}=\alpha+\beta \operatorname{Pr}+\mu_{\mathrm{t}}
$$

Where: Pr - Price of retailer; Pf - Price of farm; $\alpha$ - Constant; B - regression coefficient; $\mu_{t}$ error terms.

The value of $\alpha$ and $\beta$ can be searched by the formula:

$$
\begin{aligned}
& \beta=\frac{n \sum \operatorname{PrPf}-\sum \operatorname{Pr} \sum \operatorname{Pf}}{\sqrt{n \sum \operatorname{Pr}^{2}-\left(\sum \operatorname{Pr}\right) 2}} \\
& \alpha=P_{f}-\beta P_{r}
\end{aligned}
$$


Regression analysis of the prices of the two markets can show the degree of closeness of the relationship between the two markets. The regression coefficient aims to estimate how much price formation at the market level is influenced by the price of the commodity at other market levels (Haji J, 2014). The value of the regression coefficient $(\beta)$ is an indicator of marketing efficiency (Hodrea $R, 2015$ ), while the interpretation of the regression coefficient is the magnitude of price changes at the consumer level with the following criteria (Monke and Petzel (1984; Azzaino, 1982):

If $\beta<1$, then the market is not integrated. The market structure is monopsony or oligopsony because an increase in the price of one unit at the consumer level is followed by a price increase that is smaller than one unit at the producer level;

If $\beta=1$, then the market is perfectly integrated. The market structure is perfect competition, which means price formation between markets is more integrated with an increase in the price of one unit at the consumer level followed by an increase in the price of one unit at the producer level;

If $\beta>1$, then the market is not integrated. The market structure is monopoly or oligopoly because an increase in the price of one unit at the consumer level is followed by a price increase that is greater than one unit at the producer level.

\section{RESULTS AND DISCUSSION}

The way fish farmers' market tilapia is usually different, causing different marketing channels and the shape of the channel can be very simple, or it can be complex. The marketing channel of tilapia fish in South Kalimantan Province consists of 4 patterns which can be seen in Figure 1.

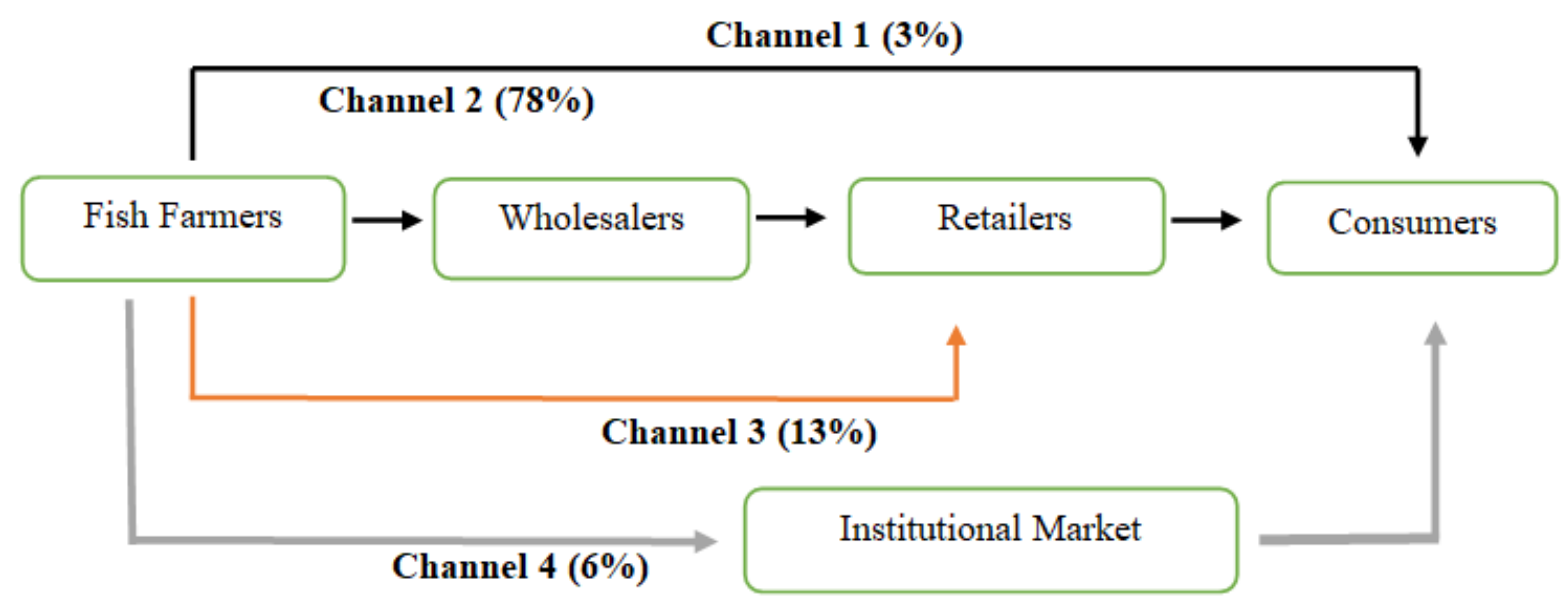

Figure 1 - Marketing channel of cultivated tilapia in South Kalimantan Province

Figure 1 explains that the marketing channel for cultivated tilapia in Banjar Regency, South Kalimantan Province consists of 4 patterns. The first channel, one of fish farmer $(3 \%)$ sold out fish to the consumer. The second channel, twenty five of fish farmers (78\%) sold out fish to the middleman and then sold again to retailers and finally sold to the consumers. Third channel, four of fish farmers (13\%) sold out to the retailers and distributed to consumers and the four channels, two of fish farmers sold fish to institutional market for distribution to consumers.

The most used pattern is channel two. Fish farmers carry out the sales process directly to collectors because traders usually come to the cultivation site to buy and immediately transport fish to be redistributed to the next buyer (Rokeya, JA, Ahmed, SS, Bhuiyan, AS, Alam, MS, 1997), in addition to Therefore, most of the cultivators strongly believe in the middleman (Rahman, Ahmadi, Mahreda, ES, 2019). Usually the collectors will pay to the farmers after the fish they have brought have been sold out (Sathiadhas, R., Kanagam, A. 
2000). Wholesalers already have their own subscriptions, namely retailers in several market areas so that they will directly distribute the fish purchased from the cultivators to the retailers (Lilimantik, E. 2013). Retailers usually make payments in cash or depending on the agreement that has been agreed with the collecting traders (Flowra, F.A., Bashar, A.H.M., Jahan, K.S.N., Samad, M.A., Islam, M.M. 2012).

Regression analysis of the prices of the two markets can show the degree of closeness of the relationship between the two markets. The regression coefficient aims to see the market structure of cultivated tilapia. The results of the regression analysis of prices at the farmer level and prices at the retail level are presented in Table 4, while the regression analysis equation model between prices at the farmer level and prices at the retail level is presented in equation 4.

$$
\mathrm{Pf}=28,054+0,55 \mathrm{Pri}
$$

Table 4 - Price regression analysis at producer level and price at retail level

\begin{tabular}{lll}
\hline No. & Description & Value \\
\hline 1. & $\alpha$ & 28,05 \\
2. & $\beta$ & 0,55 \\
3. & $R$ & 0,85 \\
4. & $\mathrm{R}^{2}$ & 0,71 \\
\hline
\end{tabular}

Source: Processed Primary Data, 2021.

Table 4 explains that from the results of the price regression analysis at the producer level and the price at the retail level, the regression coefficient value is not equal to one $(\beta<$ 1 ), which is 0.55 . This means that every price increase of IDR $1,-$ at the retail level is followed by a price increase of IDR 0.55 at the cultivator level or an increase in the price of one unit at the consumer level followed by a price increase that is smaller than one unit at the cultivator level. The value of $<1$ explains that the market is not perfectly integrated and the structure of the fish market that is formed is an oligopsony market. In this market cultivators get lower prices, this is because cultivators have no choice and are very dependent on collectors in selling their products (Lilimantik E, 2020), marketing institutions as buyers usually dominate the market (Rapsomanikis G, Hallam D and Conforti P., 2004) and they have a big role in determining prices (Joskow $P, 2005)$. Imperfect market conditions will cause the price information obtained by market participants to be imperfect (information disintegration occurs) (Sexton, RJ, Kling, CL and Carman, HF, 1991), this also causes a slow response to price adjustments so that the market becomes unstable (Ravallion M, 1986).

\section{CONCLUSION}

The marketing channel of cultivated tilapia in South Kalimantan Province consists of 4 patterns, which are (1) one of fish farmer (3\%) sold out fish to the consumer, (2) twenty five of fish farmers (78\%) sold out fish to the middleman and then sold again to retailers and finally sold to the consumers, (3) four of fish farmers (13\%) sold out to the retailers and distributed to consumers and (4) two of fish farmers sold fish to institutional market for distribution to consumers. The market structure of aquacultured tilapia is an oligopsony market, where in this form of market buyers, namely marketing agencies, usually dominate the market as recipients of goods.

\section{REFERENCES}

1. Anindita R, Baladina N., 2017. Marketing of Agricultural Products. Andi PressYogyakarta, Indonesia, 304 p.

2. Ariadi H, Meilissa M.C, Elyah $F$ and Mardiana., 2021. Financial Analysis of Tilapia (O. niloticus) Fry Businnes Activity at the Klemunan Fish Fry Center, Blitar District. Journal of Aquaculture Development and Environment, 4 (1): 227-232. 
3. Atkinson, R. and Flint, J., 2001. Accessing Hidden and Hard-to-Reach Populations: Snowball Research Strategies, Social Research, 33 (1): 1- 4.

4. Azzaino, 1982. Introduction to Agricultural Trading. Agriculture Departement. Agricultural Socio-Economic Sciences. IPB-Bogor, Indonesia.

5. Blanken P., 1992. Snowball sampling: Theoretical and practical considerations. Scientific Research. Rotterdam. 113 p.

6. Bowen, G.A., 2009. Document Analysis as a Qualitative Research Method. Qualitative Research Journal, 9 (2): 27-40.

Ciesielska M, Bostrom K.W and Ohlander M., 2008. Observation Methods. Book Chapter, in Book: Qualitative Methodologies in Organization Studies. ResearchGate. 3352.

7. Castle J.E., 2003. Maximizing research opportunities: Secondary data analysis. J Neurosci Nurs, 35: 287-290.

8. Corbin J, Morse JM., 2003. The unstructured interactive interview: Issues of reciprocity and risks when dealing with sensitive topics. Qual Inq. 9:335-54.

9. Dinas Perikanan and Kelautan, 2021. Buku Laporan Tahunan Dinas Perikanan and Kelautan Tahun 2020. Provinsi Kalimantan Selatan.

10. Dampin N, Maleewong M, 2012. Fish Growth Model for Nile Tilapia (Oreochromis niloticus) in Wastewater Oxidation Pond, Thailand. Procedia Environmental Sciences, 13: 513-524.

Eltholth M, Fornace K, Grace D, Rushton J and Hasle B., 2015. Characterisation of production, marketing and consumption patterns of farmed tilapia in the Nile Delta of Egypt. Food Policy, 51: 131-143.

11. Flowra, F.A., Bashar, A.H.M., Jahan, K.S.N., Samad, M.A., Islam, M.M. 2012. Fish marketing system and socio-economic status of Aratdars in Natore and Rajshahi, Bangladesh. Journal of Our Nature, 10(1): 34-43.

12. Gubrium J.F and Holstein J.A., 2013. The SAGE Handbook of Interview Research: The Complexity of the Craft. Sage Publication, USA. 624 p.

Haji J, 2014. Module on Agricultural Marketing and Price Analysis. School of Agricultural Economics and Agribusiness, Haramaya University. Oromia, Ethiopia. 142 p.

13. Hanafiah and Saefuddin, 1996. Marketing of Fishery Product. University of Indonesia, Jakarta. $165 \mathrm{p}$.

14. Heytens, P. J. 1986. Testing Market Integration. Food Research Institute Studies, XX (1): 25-41.

15. Husni Buton H, Pontoh O and Manoppo V.E.N. (2017). Kontribusi Pedagang Ikan Segar Di Pasar Bersehati Kelurahan Calaca Terhadap Lapangan Kerja di Kota Manado Provinsi Sulawesi Utara. Akulturasi, 5 (9): Pp 655-666.

16. Hodrea R, 2015. An intraday analysis of the market efficiency-liquidity relationship: the case of BVB stock exchange. Procedia Economics and Finance, 32: 1432-1441.

17. Johnston, M.P., 2014. Secondary Data Analysis: A Method of which the Time Has Come. Qualitative and Quantitative Methods in Libraries (QQML) 3:619 -626.

18. Joskow P, 2005. Vertical Integration, in: Handbook of New Institutional Economics. Klewer Publications. Chapter XX:1-36.

19. Kabir S.M.S., 2016. Methods of Data Collection. In book: Basic Guidelines for Research: An Introductory Approach for All Disciplines chapter 9. Publisher: Book Zone Publication, Chittagong-4203, Bangladesh. pp 201-275.

20. Kapute F, Valeta J, Jeremy $L$ and Jeremiah K., 2016. Growth performance of three tilapia fish species raised at varied pond sizes and water depths, 8(8):81-86.

21. Kartikasari D, 2010. Analysis of Commodity Distribution Pattern and Price Setting Pattern. Journal of Economics, Business, and Accountancy Ventura, 13(2): 105-121.

22. Kemisola, O.A and Anifat, O.B., 2010. Price Transmission and Market Integration of Fish in Oyo State. Journal of Rural Economics and Development, 9: 1-15.

23. Lilimantik, E. 2013. Spatial Equilibrium of Tilapia (Oreochromis niloticus bleeker) Market in South Borneo Province, Indonesia. European Journal of Business and Management, 5(5):27-36. 
24. Lilimantik E, 2020. Marketing Integration of Fishery Products. Global Science, Lowokwaru-Malang. Indonesia. $70 \mathrm{P}$.

25. Lilimantik E, Ahmadi, 2020. Institutional Analysis and Market Structure of Climbing Perch with Biofloc Culture System. Russian Journal of Agricultural and Socio-Economic Sciences, 11 (107): 117-125.

26. Mafimisebi T.E., 2008. Long-run Price Integration in Fresh Fish Marketing in Nigeria: Implications for Marketing and Development. Delhi Business Review X, 9 (1): 55-67.

27. Monke, E., Petzel, T. 1984. Market Integration: An Application to International Trade in Cotton. American Journal of Agricultural Economics, 66 (4): 481-487.

28. Parmar G, Leua A and Vanza J., 2018. Study on Fish Marketing Channel and Consumption Pattern for Fish Navsari. Multilogic in Science, III (XXV).

29. Rabinovich, E. \& Cheon, S., 2011. Expanding horizons and deepening understanding via the use of secondary data sources. Journal of Business Logistics, 32(4): 303-316.

30. Rahman, Ahmadi, Mahreda, E.S. 2019. Marketing channels of marine fish in Banjarmasin fishing port, Indonesia. International J. of Fisheries and Aquatic Research, 4(3): 15-22.

31. Rapsomanikis G, Hallam D and Conforti P., 2004. Market Integration and Price Transmission In Selected Food And Cash Crop Markets Of Developing Countries: Review And Applications. http://www.fao.org/docrep/006/y5117e/y5117e06.htm.

Ravallion M, 1986. Testing Market Integration. American Journal of Agricultural Economics, 1: 102-108.

32. Rokeya, J.A., Ahmed, S.S., Bhuiyan, A.S., Alam, M.S. 1997. Marketing system of native and exotic major carps of Rajshahi District. Bangladesh J. of Fisheries, 20 (1-2): 99- 103.

33. Sathiadhas, R., Kanagam, A. 2000. Distribution problems and marketing management of marine fisheries in India. In: Marine Fisheries Research and Management, Pillai, V.N. and Menon, N.G. (eds.). MFRI; Kochi. pp 858-875.

34. Saugat K, Sushil K., Saurav K., 2020. Production, marketing, and future prospects of fish farming in Nepal: National and Global Scenario. Cogent Food \& Agriculture. 6(1):1-19.

35. Sexton, R.J., Kling, C.L and Carman, H.F., 1991. Market Integration, Efficiency of Arbitrage, and Imperfect Competition: Methodology and Application to US Celery. American Journals for Agriculture Economics, 45: 369-380.

36. Singh S, 2003. Advanced Sampling Theory with Applications. Springer Science-Bussines Media. $1220 \mathrm{P}$.

37. Ngo T., et al, 2019. Performance of Fish Farms in Vietnam-Does Financial Access Help Improve Their Cost Efficiency? International Journal of Financial Studies, 7(45): 2-10.

38. Unget D, Mahreda E, Lilimantik E., 2020. Marketing Analysis of Siamese Catfish (Pangasius hypophthalmus) in the Kuala Kapuas Fish Market, Kuala Kapuas Distrik, Central Kalimantan Province. International Journal of Agriculture, Environment and Bioresearch, 5(2): 167-180.

39. West, P., 2016. Simple random sampling of individual items in the absence of a sampling frame that lists the individuals. New Zealand Journal of Forestry Science, 46 (15): 1-7.

Wonginyoo K, Piewthongngam K, Chatavithee P and Vorasay J., 2018. A model for restocking and harvesting aquaculture: $A$ case of multi-pond, multi-cycle, and multi-fish type farming. Biosystems Engineering, 174: 134-143. 